Instructions for authors, subscriptions and further details:

http://rasp.hipatiapress.com

\title{
An Evaluation of Successful Aging Levels of Nursing Home Residents
}

Emir Ibrahim Isik ${ }^{1}$, Ayse Inel Manav², \& Saliha Bozdogan Yesilot ${ }^{1}$

1) Cukurova University. Turkey

2) Osmaniye Korkut Ata University. Turkey

Date of publication: January $30^{\text {th }}, 2021$

Edition period: January 2021 - July 2021

To cite this article: Ibrahim Isik, E.; Inel Manav, A.; Bozdogan Yesilot, S. (2021). An Evaluation of Successful Aging Levels of Nursing Home Residents. Research on Ageing and Social Policy, 9(1), 51-78. http://10.4471/rasp.2020.5240

To link this article: http://dx.doi.org/10.447/rasp.2020.5240

\section{PLEASE SCROLL DOWN FOR ARTICLE}

The terms and conditions of use are related to the Open Journal System and to Creative Commons Attribution License (CCAL). 


\section{An Evaluation of Successful Aging Levels of Nursing Home Residents}

Emir Ibrahim Isik

Cukurova University
Ayse Inel Manav

Osmaniye Korkut Ata University

Saliha Bozdogan Yesilot

Cukurova University

(Received: 3 March 2020; Accepted: 1 July 2020; Published: 30

January 2021)

\section{Abstract}

This study was conducted to evaluate the successful aging levels of nursing home residents. This descriptive study was conducted based on Rowe and Kahn's (2015) model. The following was used to obtain data from the participants; Personal Well-Being Index-Adult, Katz Index, Standardized Mini-Mental State Examination, Social Connectedness Scale, Timed Up and Go Test, Berg Balance Scale and Handgrip Strength Test. Participants' mean scores of Personal Well-Being Index-Adult, Katz Index of Independence in Activities of Daily Living, Standardized Mini-Mental State Examination, Social Connectedness Scale, Timed Up and Go Test, Berg Balance Scale were found to be $51.68 \pm 18.60,5.53 \pm 1.38,23.57 \pm 3.02,25.23 \pm 8.89,16.10 \pm 8.81$ and $43.48 \pm 17.23$, respectively. Participants had chronic disease incidence and diabetes, adversely affected successful aging and physical functionality, respectively. Participants also had the following characteristics: vulnerable cognitive functionality, high fall risk, above average personal well-being that may positively affect aging in terms of life engagement, and social connectedness.

Keywords: successful aging, functionality, nursing home

2021 Hipatia Press

ISSN: 2014-6728

DOI: $10.447 /$ rasp. 2020.5240 


\section{Una Evaluación de los Niveles Exitosos de Envejecimiento de los Residentes de Hogares de Ancianos}

Emir Ibrahim Isik

Cukurova University
Ayse Inel Manav

Osmaniye Korkut Ata University

Saliha Bozdogan Yesilot

Cukurova University

(Recibido: 3 marzo 2020; Aceptado: 1 julio 2020; Publicado: 30 enero 2021)

\section{Resumen}

Este estudio descriptivo se realizó con base al modelo de Rowe y Kahn. Para obtener datos de los participantes de usaron los siguientes índices;; Índice de Bienestar Personal-Adulto, Katz Index, Examen Estandarizado del Estado Mini-Mental, Escala de conectividad social, Timed Up and Go Test, Escala Berg Balance y prueba de fuerza de empuñadura. Se comprobó que eran puntajes promedio de Índice de Bienestar Personal-Adulto, Katz index, Examen Estandarizado del Estado Mini-Mental, Escala de conectividad social, Timed Up and Go Test, Escala Berg Balance $51.68 \pm 18.60,5.53 \pm$ $1.38,23.57 \pm 3.02,25.23 \pm 8.89,16.10 \pm 8.81$ y $43.48 \pm 17.23$, respectivamente. Los participantes padecían enfermedades crónicas y diabetes, que afectan negativamente el envejecimiento exitoso y la funcionalidad física, respectivamente. Los participantes también tenían las siguientes características: funcionalidad cognitiva vulnerable, alto riesgo de caída, bienestar personal superior al promedio que puede afectar positivamente el envejecimiento en términos de compromiso con la vida y conexión social.

Palabras clave: envejecimiento exitoso, funcionalidad, hogar de anciano

2021 Hipatia Press

ISSN: 2014-6728

DOI: $10.447 /$ rasp. 2020.5240 


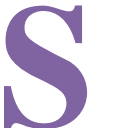

uccessful aging has been discussed since the 1960s with the increase in the elderly global population. There are various approaches regarding successful aging, measurement of successful aging levels and relevant factors (Bülow \& Söderqvist, 2014). There are also terms used such as active, healthy, productive, positive in addition to successful aging. The World Health Organization [WHO] evaluates healthy aging with a holistic approach based on lifestyle and functionality. It defines healthy aging as a process of developing and maintaining the functionality that allows wellbeing at later ages (World Health Organization, 2016).

Recently, successful aging has been evaluated with a biopsychosocial approach. Rowe and Kahn developed a model inspired from The MacArthur's Foundation Study. According to this model, successful aging has three fundamental components. These components are a low risk of disease and disability regarding the disease, high capacity of cognitive and physical functionality and active engagement with life. Rowe and Kahn state that the level of aging should be measured based on this model. Accordingly, successful aging is linked to reaching minimum value scores of the relevant scales (Rowe \& Kahn, 1997, 2015).

The number of elderly people is increasing globally as well as in Turkey, and protecting and maintaining the quality of lives of these people becomes more important. Elderly people who are aging successfully can actively maintain their lives with well-being, high levels of functionality and active participation in life. The concept of successful aging has not only been widely cited in the geriatrics, gerontology and ageing research literature, but also by researchers from nursing science, odontology, psychology, sociology, political science, and other fields of broad relevance to the medical, social, cultural and political understandings of ageing (Bülow \& Söderqvist, 2014). For this reason, evaluating the levels of successful aging of the elderly is significant in terms of supporting successful aging and battling against the elements that adversely affect successful aging. Literature includes studies regarding successful aging in various societies. In their studies conducted with elderly Latin Americans in Mexico; Arias-Merino, Mendoza-Ruvalcaba, Arias-Merino, Cueva-Contreras, \& Vazquez Arias (2012) have indicated that $12.6 \%$ of the elderly aged successfully. Dahany et al. (2014) have found $29.9 \%$ of the elderly aged successfully in their studies conducted to examine factors regarding successful aging in Philippines. 
Recent studies have also shown that successful aging is linked to culture. No studies have been conducted regarding the evaluation of successful aging in Turkey. Therefore, it is important to research successful aging in Turkish culture. This descriptive study was conducted to evaluate the successful aging levels of nursing home residents.

\section{Methodology}

\section{Study Participants}

This descriptive study was conducted to evaluate the successful aging levels of nursing home residents. Çukurova University Clinic Studies Ethics Committee and Adana Provincial Directorate of the Ministry of Family and Social Policies gave written permission for the study. No special grant was received from any fund committee for this study.

Study participation was voluntary. Informed consent forms were obtained from all volunteers who participated in the study. With the consent forms, patients who gave consent to participate in the study were informed that factors such as privacy and confidentiality would be preserved, and they could withdraw from the study at any time.

The study was conducted in two institutions; Şehit Kr. Pilot Serhat Sığnak Nursing Home, Elderly Care and Rehabilitation Center which is affiliated with Adana Provincial Directorate of the Ministry of Family and Social Policies and Seyhan Nursing Home, Elderly Care and Rehabilitation Center. These two nursing homes were public institutions. In both centers, there were indoor and outdoor areas where there are various service units such as library, multi-purpose hall, art workshop, cafeteria, tailor, hairdresser, instrument sports area for elderly individuals who live in the center.

The study population included all elderly people residing in both institutions. Study inclusion criteria were as follows: being over 65 years of age, not being diagnosed with dementia, not being in a terminal stage. Exclusion criteria for this study was not determined. There were 312 nursing home residents in both institutions. Of these residents, 212 were diagnosed with dementia and/or in a terminal stage. Thus, the study population included 100 elderly residents living in the relevant institutions and meeting the inclusion criteria. Calculation done with the simple randomization sampling method ( $80 \%$ power with a significance level of 0.05$)$ determined that at least 
80 elderly people should be included in the study for $80 \%$ power with a significance level of 0.05 (Trost, 1986). This study involved 87 elderly residents who met the inclusion criteria.

\section{Assessment Tools}

Study data were collected with the following forms and tools.

\section{Personal Information Form}

The researcher created an introductory information form based on literature. This form included 11 questions regarding individuals' socio-demographic characteristics (age, gender, marital status, education status, profession, etc.) and chronic disease history.

\section{Personal Well-Being Index-Adult Form}

Personal Well-Being Index-Adult (PWI-A) is a thematic measurement tool using a 11-point Likert-type scale (0-10) aiming to measure subjective wellbeing through satisfaction levels regarding eight life domains. Life domains measured by the PWI-A included standard of living, personal health, achieving in life, personal relationships, personal safety, community connectedness/belonging, future security, and spirituality/religion. The International Well-Being Group led by Cummins developed the PWI-A form (Lau, Cummins, \& Mcpherson, 2005; Misajon, Pallant, \& Bliuc, 2016). Each of the eight life domains to be measured via the PWI-A form was measured with eight questions through one item. This 11-point Likert-type form (0: No Satisfaction at All, 5: neutral, 10: Completely Satisfied) did not include reversed items. The minimum and maximum score possible on the scale is 0 and 80, respectively. Meral examined the psychometric characteristics of the PWI-A Turkish version form through an adult sample in Turkey in 2014. The internal consistency coefficient was accounted as 0.81 , item total correlations showed good level representativeness, and the scale provided the criterion validity. The PWI-A form was determined to be qualified to measure personal well-being within the scope of positive psychology and quality of life studies 
in Turkey (Meral, 2014). We used Meral's PWI-A Turkish version in this study.

\section{Katz Index of Independence in Activities of Daily Living}

Activities of Daily Living index was developed by Katz et al. in 1963. Its Turkish validity and reliability study were conducted by Ar1k et al. (2015). This index determines activities about meeting the fundamental and necessary needs for maintaining life. The ADL index includes six questions regarding bathing, dressing, toileting, transferring, continence and feeding activities. 0 is evaluated as dependence and 1 as independence for each question in this index. In total, 6 is evaluated as full independence and 0 is evaluated as full dependence (Arik et al. 2015; Katz, Ford, Moskowitz, Jackson, \& Jaffe, 1963).

\section{Standardized Mini-Mental State Examination}

Folstein et al. developed this scale to evaluate cognitive inefficacy. Applicability of the Standardized Mini-Mental State Examination (SMMSE) increased with the Standardized Mini-Mental State Examination Guide developed by Folstein, Folstein, \& McHugh (1975) and Moore, Metcalf, \& Schow (2006). This test includes 11 items covers five main themes as orientation to time and place, registration, recall, attention and calculation, and language. Each correct answer is one point in SMMSE, which is evaluated out of 30 points. Güngen et al. conducted a Turkish validity and reliability study of SMMSE in 2002 (Güngen, Ertan, Eker, Yaşar, \& Engin, 2002). SMMSE scores between 23 and 18, between 17 and 10 and 10 and below indicate mild/early stage, moderate stage, and severe stage, respectively. The limit for dementia is accepted as 23/24 (Keskinoglu et al., 2009). The researcher performed SMMSE according to the education level of the individuals.

\section{Social Connectedness Scale}

The Social Connectedness Scale (SCS) developed by Lee and Robbins in 1995 includes eight items measuring the level of social connectedness which 
is a significant part of an individuals' belonging feelings. The 6-point Likerttype scale ranges from strongly agree to strongly disagree. High scores indicate high social connectedness. This scale does not include any reversed items (Lee \& Robbins, 1995). Turkish adaptation was conducted by Duru (2007). Internal consistency Cronbach's Alpha coefficient of the scale was found to be 90 (Duru, 2007).

\section{Timed Up and Go Test}

The Timed Up and Go Test (TUG) is used to determine the functional mobility level and fall risk. The individuals are asked to stand up from a standard arm chair while their feet touch the ground, walk a distance of 3 meters, turn 180 degrees, walk back to the chair, and sit down. The completion process of the test is recorded with a stopwatch in seconds. Those who complete the test in over 13.5 seconds are accepted to have a fall risk (Ekström, Dahlin-Ivanoff, \& Elmståhl, 2011; Podsiadlo \& Richardson, 1991).

\section{Berg Balance Scale}

Berg Balance Scale including 14 tasks of different postures is a scale used to evaluate balance. This scale evaluates the following abilities: sitting supported, sitting to standing, sitting unsupported, standing unsupported, standing to sitting, transfers, standing unsupported with eyes closed, standing unsupported with feet together, reaching forward with outstretched arm while standing, picking up an object from the floor from a standing position, turning to look behind over the left and right shoulders while standing, turning 360 degrees, placing the alternate foot on a step or stool while standing unsupported, standing unsupported one foot in front and standing on one leg. In each posture, 0 indicates that the task was not completed whereas 4 indicates that the task was completed normally. The maximum obtainable score is 56 . A score between 0 and 20 indicates the individual is wheelchairbound and has a $100 \%$ fall risk. A score between 21 and 40 indicates the individual can walk with help because of having a fall risk. A score between 41-56 indicates the individual can walk independently (Bogle Thorbahn \& Newton, 1996; Sahin et al., 2008). 


\section{Handgrip Strength Test}

Jamar hydraulic system hand dynamometer was used for the measurement of handgrip strength. The dynamometer has a dual scale readout displaying all measurement values within the range of $0-200$ pounds $(90 \mathrm{~kg})$ on an analog monitor. Analog monitor displays measurement results in pounds or kilograms (Bellace, Healy, Besser, Byron, \& Hohman, 2000).

\section{Statistical Analysis}

Study findings were evaluated using IBM SPSS Statistics V22.0 (IBM SPSS, Turkey) software for statistical analysis. Variables' suitability to normal distribution was examined using Shapiro-Wilk Test. Study data were evaluated using descriptive statistical methods (mean, standard deviation, frequency). Mann Whitney U test was used in the evaluations of quantitative data between the two groups. Kruskal Wallis test was used in the inter-group evaluation of more than two groups of quantitative data. Mann Whitney U test was used in the determination of the group causing a difference. Spearmen Rho Correlation Analysis was used in the evaluation of the relationship between quantitative data. The significance level was evaluated at $\mathrm{p}<0.05$.

\section{Results}

This study was conducted with 87 elderly people. Of the participants, $42.5 \%$ were female $(\mathrm{n}=37), 57.5 \%$ were male $(\mathrm{n}=50)$. Participants' ages ranged from 65 to 96 . The mean age and median were found to be $73.01 \pm 6.30$ and 72 , respectively. Of the participants, $64.4 \%(n=56)$ were under 75 years old.

The BMI indices ranged from 16.14 to $54.69 \mathrm{~kg} / \mathrm{m}^{2}$. The mean BMI index score and median were found to be $27.58 \pm 6.30$ and $26.53 \mathrm{~kg} / \mathrm{m}^{2}$, respectively. Of the participants, $41.4 \%(\mathrm{n}=36)$ were overweight, $57.5 \%(\mathrm{n}=50)$ were male, $69 \%(\mathrm{n}=60)$ were single, $31 \%(\mathrm{n}=27)$ were primary school graduates, $97.7 \%$ $(\mathrm{n}=85)$ did not work, 64.4\% $(\mathrm{n}=56)$ had equal income and expenditures and $34.5 \%(n=30)$ were smokers. And of the married participants, $88.9 \%(n=24)$ had a living spouse. 
60 Isik et al. - Successful Aging Levels of Nursing Home Residents

Of all participants, $58.6 \%(\mathrm{n}=51)$ had a chronic disease. Of these participants, $60.8 \%(\mathrm{n}=31), 52.9 \%(\mathrm{n}=27)$ and $9.8 \%(\mathrm{n}=5)$ had hypertension, diabetes, and chronic heart failure, respectively (Table 1).

Table 1

Distribution of descriptive characteristics of the elderly participants $(N=87)$

\begin{tabular}{|c|c|c|c|}
\hline & & Min-Max & Mean \pm SD (Median) \\
\hline Age (year) & & $65-96$ & $73.01 \pm 8.03(72)$ \\
\hline \multirow[t]{2}{*}{ BMI $\left(\mathrm{kg} / \mathrm{m}^{2}\right)$} & & $16.14-54.69$ & $27.58 \pm 6.30(26.53)$ \\
\hline & & $\mathrm{n}$ & $\%$ \\
\hline \multirow{2}{*}{ Age group } & 75 and under & 56 & 64.4 \\
\hline & 75 and over & 31 & 35.6 \\
\hline \multirow{2}{*}{ Gender } & Female & 37 & 42.5 \\
\hline & Male & 50 & 57.5 \\
\hline \multirow{6}{*}{ BMI group } & Underweight & 3 & 3.4 \\
\hline & Normal & 26 & 29.9 \\
\hline & Overweight & 36 & 41.4 \\
\hline & Class 1 obesity & 16 & 18.4 \\
\hline & Class 2 obesity & 4 & 4.6 \\
\hline & Class 3 obesity & 2 & 2.3 \\
\hline \multirow{2}{*}{ Marital Status } & Single & 60 & 69.0 \\
\hline & Married & 27 & 31.0 \\
\hline \multirow{2}{*}{$\begin{array}{l}\text { Spouse is alive } \\
(\mathrm{n}=27)\end{array}$} & Yes & 24 & 88.9 \\
\hline & No & 3 & 11.1 \\
\hline \multirow{6}{*}{ Educational Level } & Illiterate & 16 & 18.4 \\
\hline & Literate & 18 & 20.7 \\
\hline & Primary School & 27 & 31.0 \\
\hline & Middle School & 10 & 11.5 \\
\hline & High School & 8 & 9.2 \\
\hline & College and above & 8 & 9.2 \\
\hline \multirow{2}{*}{ Working } & Yes & 2 & 2.3 \\
\hline & No & 85 & 97.7 \\
\hline \multirow{3}{*}{ Income Status } & Income $<$ Expenditure & 27 & 3.0 \\
\hline & Income $=$ Expenditure & 56 & 64.4 \\
\hline & Income $>$ Expenditure & 4 & 4.6 \\
\hline \multirow{2}{*}{ Chronic disease } & Yes & 51 & 58.6 \\
\hline & No & 36 & 41.4 \\
\hline
\end{tabular}


Table 1 (Continued)

Distribution of descriptive characteristics of the elderly participants $(N=87)$

\begin{tabular}{llcc}
\hline & & Min-Max & Mean \pm SD (Median) \\
\hline Age (year) & & $65-96$ & $73.01 \pm 8.03(72)$ \\
\hline BMI $\left(\mathrm{kg} / \mathrm{m}^{2}\right)$ & & $16.14-54.69$ & $27.58 \pm 6.30(26.53)$ \\
\hline \multirow{4}{*}{ Chronic diseases } & $\mathrm{n}$ & $\%$ \\
$(\mathrm{n}=51)$ & Hypertension & 31 & 60.8 \\
& Diabetes & 27 & 52.9 \\
& Chronic heart failure & 5 & 9.8 \\
& Stroke & 4 & 7.8 \\
& COPD & 3 & 5.9 \\
& Bronchitis & 2 & 3.9 \\
& Chronic renal failure & 1 & 2.0 \\
& Asthma & 1 & 2.0 \\
\multirow{2}{*}{ Smoking } & Migraine & 1 & 2.0 \\
& Yes & 30 & 34.5 \\
& No & 57 & 65.5 \\
\hline
\end{tabular}

*More than one option was chosen.

The PWI-A indices ranged from 2 to 80 . The mean PWI-A scores and median were found to be $51.68 \pm 18.60$ and 53 , respectively. Internal consistency coefficient was determined to be 0.803 for this index (Cronbach's Alpha). The ADL indices ranged from 0 to 6 . The mean ADL scores and median were found to be $5.53 \pm 1.38$ and 6 , respectively. Internal consistency coefficient was calculated to be 0.928 for this index (Kuder Richardson 20). SMMSE ranged from 18 to 30. The mean SMMSE scores and median were found to be $23.57 \pm 3.02$ and 23 , respectively. Internal consistency coefficient was determined to be 0.779 for this test (Cronbach's Alpha). The SCS scores ranged from 6 to 36. The mean SCS scores and median were found to be $25.23 \pm 8.89$ and 27 , respectively. Internal consistency coefficient was determined to be 0.949 for this scale (Cronbach's Alpha). TUG scores ranged from 0 to 49.1. The mean TUG scores and median were found to be $16.10 \pm 8.81$ and 15 , respectively. BBS scores ranged from 0 to 56 . Their mean BBS scores and median were found to be $43.48 \pm 17.23$ and 52, respectively. HST measurement scores for right hand ranged from 0 to 90 and the mean score and median were found to be $46.56 \pm 19.31$ and 45 , respectively. HST 
62 Isik et al. - Successful Aging Levels of Nursing Home Residents

measurement scores for left hand ranged from 0 to 88 and the mean score and median were found to be $42.45 \pm 19.25$ and 40 , respectively (Table 2).

Table 2

Distribution of individuals' scores and indices

\begin{tabular}{|c|c|c|c|}
\hline & & Min-Max & Mean \pm SD (Median) \\
\hline PWI-A & & $2-80$ & $51.68 \pm 18.6(53)$ \\
\hline ADL & & $0-6$ & $5.53 \pm 1.38(6)$ \\
\hline SMMSE & & $18-30$ & $23.57 \pm 3.02(23)$ \\
\hline SCS & & $6-36$ & $25.23 \pm 8.89(27)$ \\
\hline TUG & & $0-49.1$ & $16.10 \pm 8.81(15)$ \\
\hline BBS & & $0-56$ & $43.48 \pm 17.23(52)$ \\
\hline \multirow[t]{2}{*}{ HST } & Right & $0-90$ & $46.56 \pm 19.31(45)$ \\
\hline & Left & $0-88$ & $42.45 \pm 19.25(40)$ \\
\hline
\end{tabular}

Note. PWI-A: Personal Well-Being Index-Adult; ADL: Katz Index of Independence in Activities of Daily Living (ADL); SMMSE Standardized Mini-Mental State Examination SCS: Social Connectedness Scale; TUG: Timed Up and Go Test; BBS: Berg Balance Scale; HST: Handgrip Strength Test.

A statistically positive significant relationship was found between PWI-A indices and ADL indices (p:0.009), between PWI-A indices and SCS scores (p:0.001), between PWI-A indices and BBS scores (p:0.019) at the level of $27.7 \%, 55.6 \%$ and $25.3 \%$, respectively $(\mathrm{p}<0.05 ; \mathrm{p}<0.01)$. A statistically positive significant relationship was found between ADL indices and BBS scores (p:0.001), ADL indices and HST measurement for right hand scores (p:0.007) and between ADL indices and HST measurement for left hand scores (p:0.001) at the level of $60.2 \%, 28.8 \%$ and $47.8 \%$, respectively $(\mathrm{p}<0.01)$. A statistically positive significant relationship was found between SMMSE scores and BBS scores (p:0.027) and between SMMSE scores and HST measurement for the right hand (p:0.030) at the level of $24.1 \%$ and $23.3 \%$, respectively $(\mathrm{p}<0.05)$. A statistically negative significant relationship was found between SCS scores and TUG test at the level of 26.1\% (p:0.017; $\mathrm{p}<0.05)$. A statistically positive significant relationship was found between SCS scores and BBS (p:0.011) and between SCS scores and HST measurement for the right hand (p:0.021) at the level of $27.3 \%$ and $24.8 \%$, respectively $(\mathrm{p}<0.05)$. A statistically positive significant relationship was found between BBS and HST measurement for right hand (p:0.001) and 
between BBS and HST measurement for left hand (p:0.001) at the level of 49.1\% and 45.5\%, respectively (p<0.01) (Table 3).

Table 3

Correlation evaluation of scale scores and indices

\begin{tabular}{|c|c|c|c|c|c|c|c|c|}
\hline & PWI-A & ADL & SMMSE & SCS & TUG & BBS & Right-HST & Left-HST \\
\hline & $\mathbf{r} ; \mathbf{p}$ & $\mathbf{r} ; \mathbf{p}$ & $\mathbf{r} ; \mathbf{p}$ & $\mathbf{r} ; \mathbf{p}$ & $\mathbf{r} ; \mathbf{p}$ & $\mathbf{r} ; \mathbf{p}$ & $\mathbf{r} ; \mathbf{p}$ & $\mathbf{r} ; \mathbf{p}$ \\
\hline PWI-A & 1 & - & - & - & - & - & - & - \\
\hline ADL & $0.277 ; 0.009 * *$ & 1 & - & - & - & - & - & - \\
\hline SCS & $0.556 ; 0.001 * *$ & $0.144 ; 0.185$ & $0.085 ; 0.435$ & 1 & - & - & - & - \\
\hline TUG & $-0.135 ; 0.219$ & $0.121 ; 0.272$ & $-0.209 ; 0.056$ & $\begin{array}{l}-0.261 \\
0.017 *\end{array}$ & 1 & - & - & - \\
\hline $\begin{array}{l}\text { Right- } \\
\text { HST }\end{array}$ & $0.132 ; 0.224$ & $\begin{array}{c}0.288 \\
0.007 * *\end{array}$ & $0.233 ; 0.030 *$ & $0.248 ; 0.021^{*}$ & $\begin{array}{c}-0.145 \\
0.188\end{array}$ & $\begin{array}{c}\text { 0.491; } \\
0.001 * *\end{array}$ & 1 & - \\
\hline Left-HST & $0.146 ; 0.177$ & $\begin{array}{c}\text { 0.478; } \\
0.001 * *\end{array}$ & $0.185 ; 0.086$ & $0.090 ; 0.405$ & $\begin{array}{c}-0.007 \\
0.949\end{array}$ & $\begin{array}{c}0.455 \\
0.001 * *\end{array}$ & $\begin{array}{c}0.829 \\
0.001 * *\end{array}$ & 1 \\
\hline
\end{tabular}

r: Spearman rho Correlation Analysis

$* \mathrm{p}<0.01 \quad * * \mathrm{p}<0.01$

SCS scores of individuals who were 75 years old and over were statistically significantly higher than those who were 75 years and under (p:0.009; $\mathrm{p}<0.01)$. SCS score of individuals who had equal or more income than expenditure was statistically significantly higher than those who had lower income than expenditure ( $\mathrm{p}: 0.004 ; \mathrm{p}<0.01)$. ADL indices of individuals who did not have diabetes were statistically significantly higher than those who had diabetes (p:0.012; 
64 Isik et al. - Successful Aging Levels of Nursing Home Residents

$\mathrm{p}<0.05$ ). TUG Test scores of individuals who were 75 years old and over were statistically significantly higher than those who were 75 years and under (p:0.005; $\mathrm{p}<0.01)$ (Table 4, Table 5).

Table 4

Evaluation of PWI-A, ADL, SMMSE and SCS scale scores based on individuals' introductory characteristics

\begin{tabular}{|c|c|c|c|c|c|}
\hline \multirow{2}{*}{\multicolumn{2}{|c|}{ Introductory Characteristics }} & PWI-A & $\mathrm{ADL}$ & SMMSE & SCS \\
\hline & & $\begin{array}{r}\text { Mean } \pm \text { SD } \\
(\text { Median) }\end{array}$ & $\begin{array}{r}\text { Mean } \pm \text { SD } \\
\text { (Median) }\end{array}$ & $\begin{array}{c}\text { Mean } \pm \text { SD } \\
(\text { Median) }\end{array}$ & $\begin{array}{r}\text { Mean } \pm \text { SD } \\
(\text { Median) }\end{array}$ \\
\hline \multirow{4}{*}{$\begin{array}{l}\text { Age } \\
\text { group }\end{array}$} & 75 and under & $\begin{array}{c}52.30 \pm 17.64 \\
(53)\end{array}$ & $\begin{array}{c}5.54 \pm 1.31 \\
(6)\end{array}$ & $\begin{array}{c}23.55 \pm 2.86 \\
(23) \\
\end{array}$ & $\begin{array}{c}27.00 \pm 8.51 \\
(29)\end{array}$ \\
\hline & 75 and over & $\begin{array}{c}50.55 \pm 20.47 \\
(55) \\
\end{array}$ & $\begin{array}{c}5.52 \pm 1.52 \\
(6)\end{array}$ & $\begin{array}{c}23.61 \pm 3.33 \\
(24) \\
\end{array}$ & $\begin{array}{c}22.03 \pm 8.80 \\
(23)\end{array}$ \\
\hline & $\mathbf{Z}$ & -0.084 & -0.887 & -0.125 & -2.600 \\
\hline & $\mathbf{p}$ & 0.933 & 0.375 & 0.901 & $0.009 * *$ \\
\hline \multirow{4}{*}{ Gender } & Female & $\begin{array}{c}50.00 \pm 18.26 \\
(53) \\
\end{array}$ & $\begin{array}{c}5.16 \pm 1.72 \\
(6) \\
\end{array}$ & $\begin{array}{c}23.70 \pm 3.21 \\
(24) \\
\end{array}$ & $\begin{array}{c}25.65 \pm 8.42 \\
(28) \\
\end{array}$ \\
\hline & Male & $\begin{array}{c}52.92 \pm 18.94 \\
(54) \\
\end{array}$ & $\begin{array}{c}5.80 \pm 0.99 \\
(6) \\
\end{array}$ & $\begin{array}{c}23.48 \pm 2.89 \\
(23) \\
\end{array}$ & $\begin{array}{c}24.92 \pm 9.29 \\
(26.5) \\
\end{array}$ \\
\hline & $\mathbf{Z}$ & -0.816 & -3.214 & -0.384 & -0.284 \\
\hline & $\mathbf{p}$ & 0.415 & $0.001 * *$ & 0.701 & 0.776 \\
\hline \multirow{5}{*}{$\begin{array}{l}\text { BMI } \\
\text { group }\end{array}$} & $\begin{array}{l}\text { Underweight/Normal } \\
\text { weight }\end{array}$ & $\begin{array}{c}56.59 \pm 14.16 \\
(59)\end{array}$ & $\begin{array}{c}5.90 \pm 0.31 \\
(6) \\
\end{array}$ & $\begin{array}{c}23.48 \pm 3.14 \\
(22) \\
\end{array}$ & $\begin{array}{l}25.17 \pm 9.24 \\
(27)\end{array}$ \\
\hline & Overweight & $\begin{array}{c}50.47 \pm 20.11 \\
(50)\end{array}$ & $\begin{array}{l}5.56 \pm 1.50 \\
(6)\end{array}$ & $\begin{array}{c}23.81 \pm 2.70 \\
(24)\end{array}$ & $\begin{array}{c}25.08 \pm 8.36 \\
(24.5)\end{array}$ \\
\hline & Obese & $\begin{array}{c}47.18 \pm 20.47 \\
(50.5) \\
\end{array}$ & $\begin{array}{c}5.00 \pm 1.85 \\
(6) \\
\end{array}$ & $\begin{array}{c}23.32 \pm 3.44 \\
(22) \\
\end{array}$ & $\begin{array}{c}25.55 \pm 9.65 \\
(28) \\
\end{array}$ \\
\hline & $\chi^{2}$ & 2.350 & 5.357 & 0.802 & 0.218 \\
\hline & $\mathbf{p}$ & 0.309 & 0.052 & 0.670 & 0.897 \\
\hline \multirow{4}{*}{$\begin{array}{l}\text { Marital } \\
\text { Status }\end{array}$} & Single & $\begin{array}{c}52.40 \pm 17.24 \\
(53) \\
\end{array}$ & $\begin{array}{c}5.42 \pm 1.52 \\
(6) \\
\end{array}$ & $\begin{array}{c}23.02 \pm 2.99 \\
(22) \\
\end{array}$ & $\begin{array}{c}25.22 \pm 9.09 \\
(27) \\
\end{array}$ \\
\hline & Married & $\begin{array}{c}50.07 \pm 21.59 \\
(55) \\
\end{array}$ & $\begin{array}{c}5.78 \pm 0.97 \\
(6) \\
\end{array}$ & $\begin{array}{c}24.81 \pm 2.73 \\
(25) \\
\end{array}$ & $\begin{array}{c}25.26 \pm 8.59 \\
(25) \\
\end{array}$ \\
\hline & $\mathbf{Z}$ & -0.289 & -1.317 & -2.703 & -0.018 \\
\hline & $\mathbf{p}$ & 0.773 & 0.188 & $0.007 * *$ & 0.985 \\
\hline
\end{tabular}


Table 4 (Continued)

Evaluation of PWI-A, ADL, SMMSE and SCS scale scores based on individuals' introductory characteristics

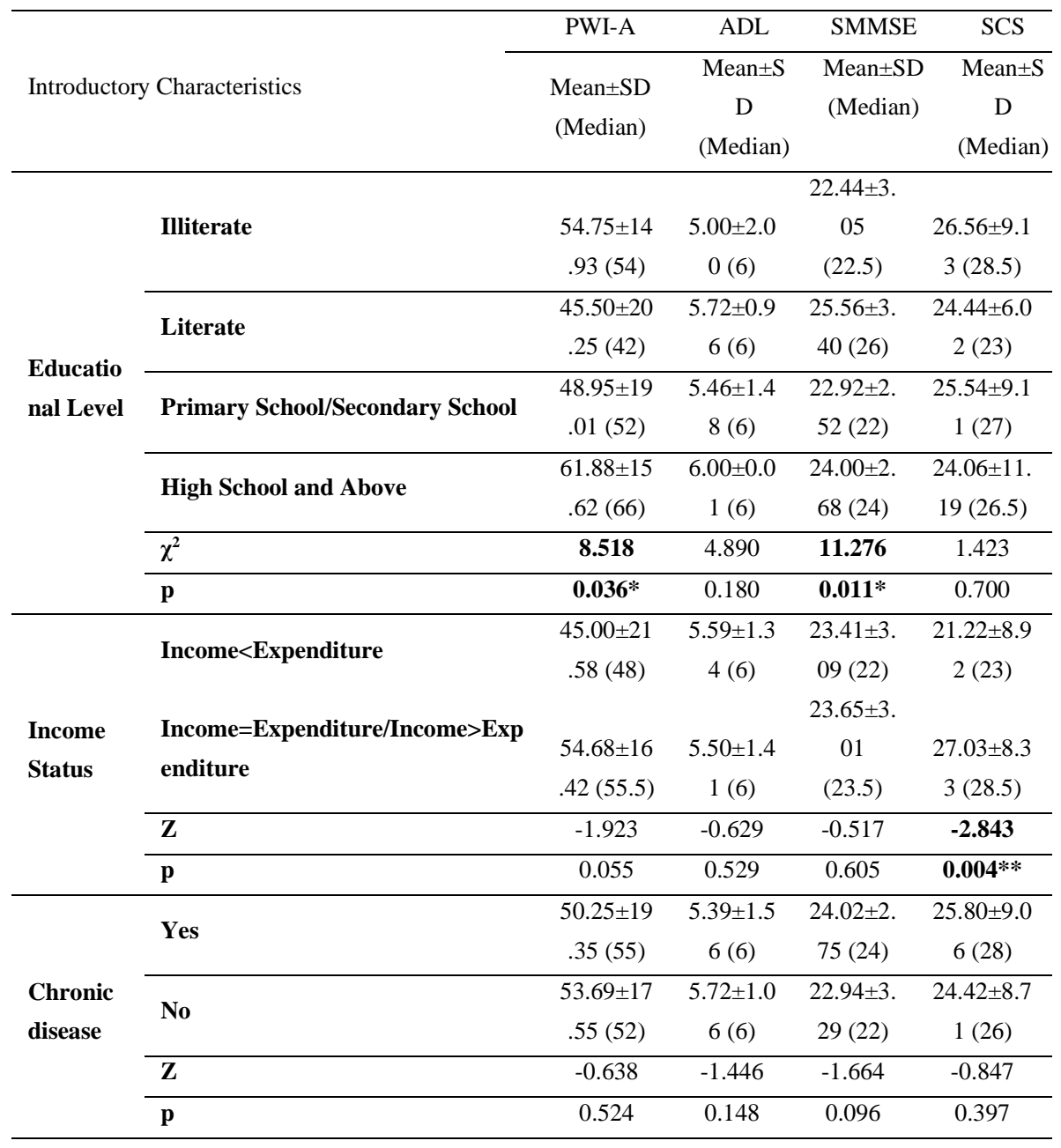


66 Isik et al. - Successful Aging Levels of Nursing Home Residents

Table 4 (Continued)

Evaluation of PWI-A, ADL, SMMSE and SCS scale scores based on individuals' introductory characteristics

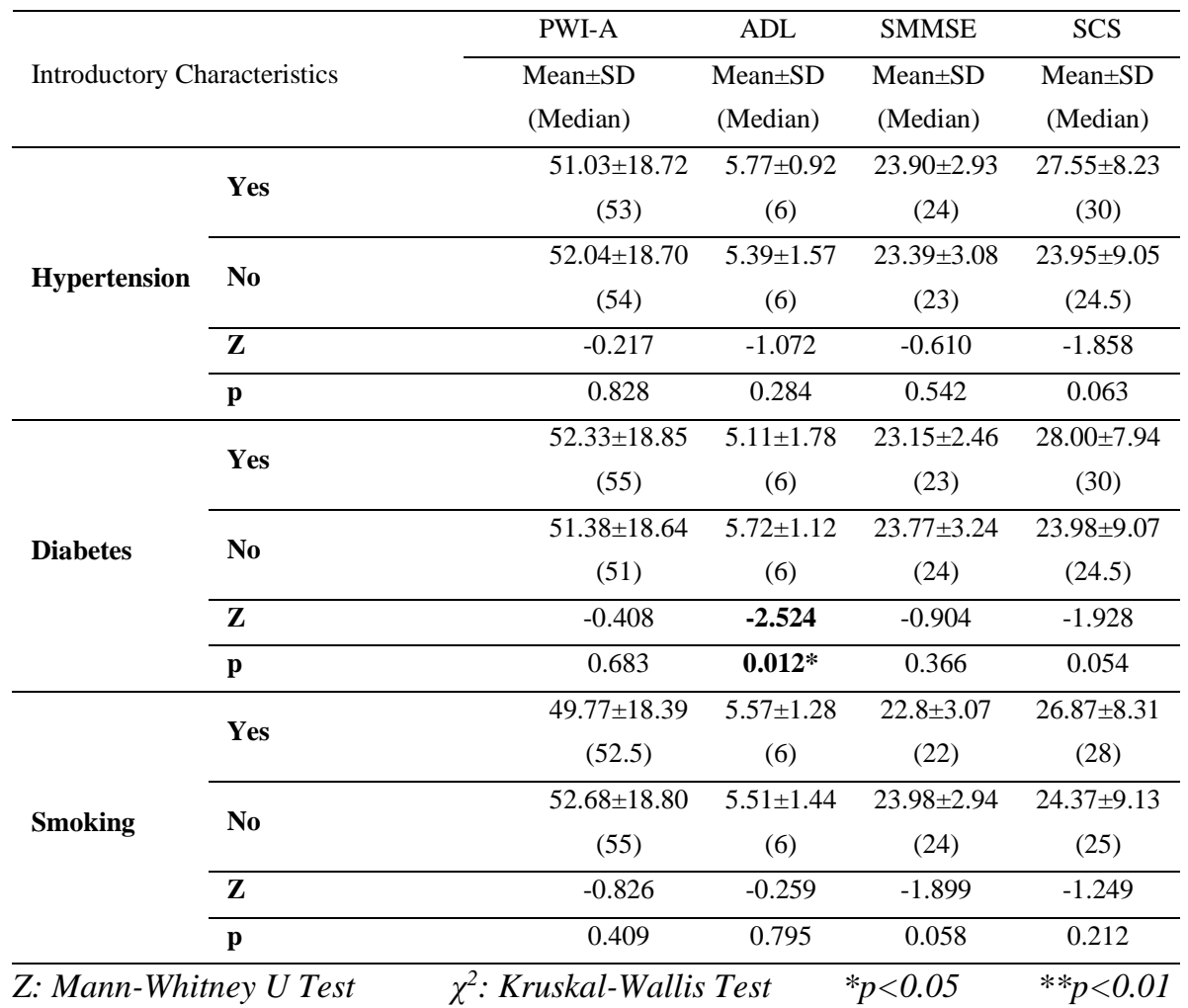


Table 5

Evaluation of TUG, BBS, Right-HST and Left-HST scale scores according to individuals' introductory characteristics

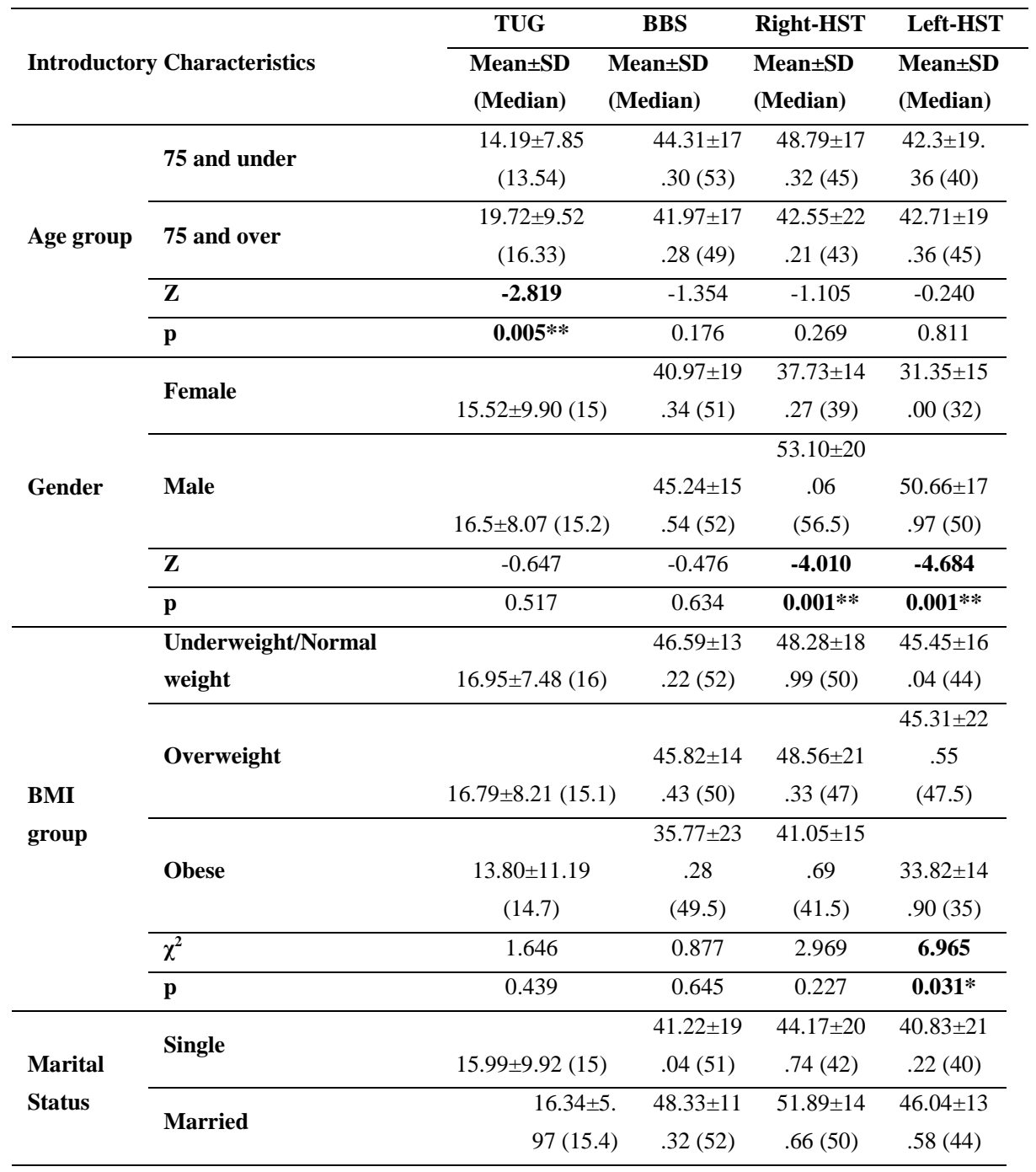


68 Isik et al. - Successful Aging Levels of Nursing Home Residents

Table 5 (Continued)

Evaluation of TUG, BBS, Right-HST and Left-HST scale scores according to individuals' introductory characteristics

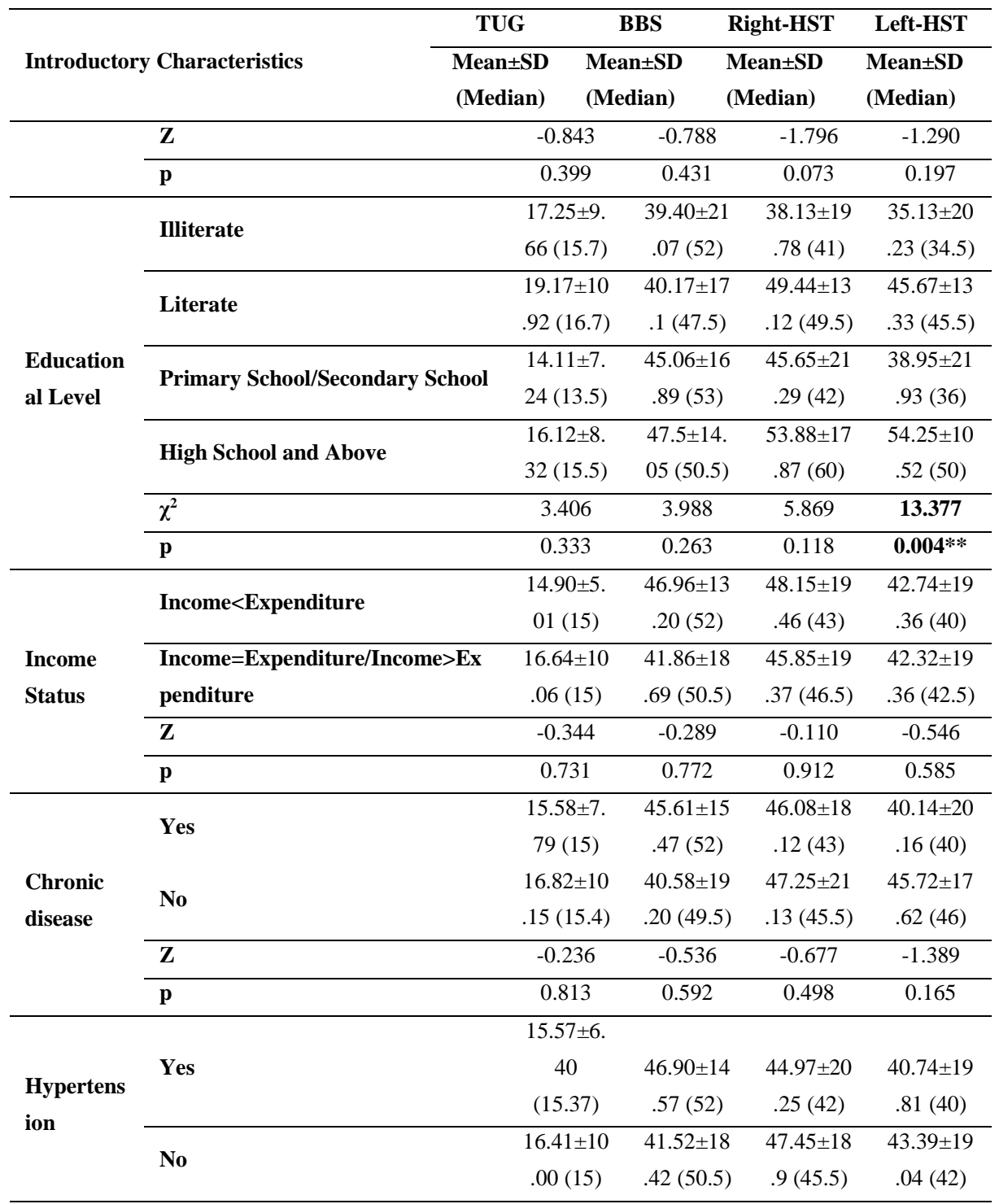


Table 5 (Continued)

Evaluation of TUG, BBS, Right-HST and Left-HST scale scores according to individuals' introductory characteristics

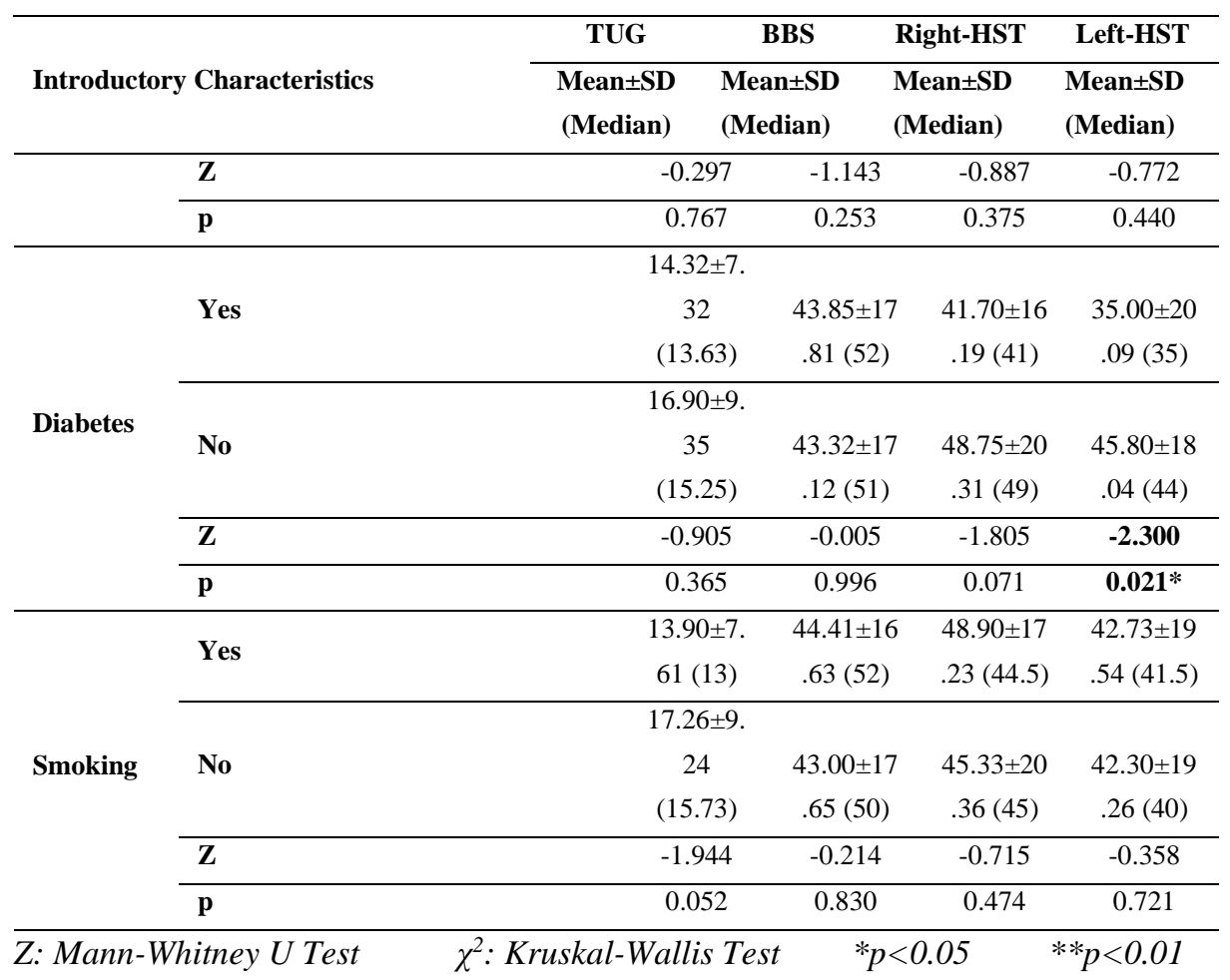

\section{Discussion}

This study is significant in terms of investigating the level of successful aging of nursing home residents and revealing findings that indicated successful aging in a population which has not been sufficiently investigated before.

This study evaluated the level of successful aging of elderly individuals based on the Rowe and Kahn model. Discussion section of this study was also written based on this model (Rowe \& Kahn, 2015). This model determines 


\section{Isik et al. - Successful Aging Levels of Nursing Home Residents}

whether successful aging was achieved or not by evaluating disease, level of disability regarding the disease, level of physical and cognitive functionality and active engagement with life. Accordingly, when study findings were evaluated in terms of disease and level of disability regarding the disease, at least one chronic disease was detected in the elderly participating in this study (Table 1).

Age is a significant risk factor for non-communicable chronic diseases such as chronic obstructive pulmonary disease, cardiovascular disorder, and type 2 diabetes (Dent et al., 1999). In their systematic review study, Marengoni et al. (2011) have reported the rate of incidence of chronic disease in the elderly as between $55 \%$ and $98 \%$. This study results also shows a similar range as the study by Marengoni et al. (2011). It is close to the lower limit of the range. Hypertension and diabetes were seen more than other chronic diseases in the participants of this study (Table 1). According to WHO, of non-communicable diseases, $48 \%$ are cardiovascular disease, $21 \%$ are cancer, $12 \%$ are chronic respiratory disease and $3.5 \%$ are diabetes. These diseases are among the most common reasons for mortality in the world. The hypertension rate in the adult Turkish population is $16.2 \%$ and the diabetic rate is $9.1 \%$. The incidence rate of each disease increases with age. In Turkish individuals aged 70 years and over, the use of hypertension and diabetes medication rates are $85.4 \%$ and 28.8\%, respectively (Üner, Balc1lar, \& Ergüder, 2018). Individuals participating in this study had similar chronic diseases with Turkish society, which was expected. Of the elderly participants, $41.4 \%$ were overweight, which was a significant risk factor increasing the incidence rate of diabetes. The study by Chiaranai et al. also has similar results with this study (Chiaranai, Chularee, \& Srithongluang, 2018).

This study showed that the elderly without diabetes were more active in the activities of daily living compared to those with diabetes (Table 4). In their meta-analysis study, Wong et al. (2013) have stated that diabetes caused a major increase in physical disability. Günal et al.(2012) have determined that patients over the age of 60 showing functional disability related to diabetes have higher disability perceptions. For this reason, there is benefit in focusing on the perception of disability in addition to physical interventions (Günal, et al. 2012). Effective management of diabetes in elderly individuals has a significant effect in increasing activities of daily living when diabetes incidence and perception of disability in the studies were considered. 
Accordingly, active management of diabetes may positively affect the level of successful aging as it can increase participation in activities of daily living. When study results were evaluated in terms of physical functionality, TUG, BBS, and HST measurement were conducted for physical functionality. This study found the mean TUG score to be $16.10 \pm 8.81$ (Table 2). Mean TUG score is an important test evaluating mobility and balance. A descriptive metaanalysis by Bohannon has found normal value to be 9.4 for the ages between 60 and 99 (Bohannon, 2006). Accordingly, individuals participating in this study had a duration longer than this determined normal value. Duration has been found longer in the study by Bohannon, which may be related to study including elderly people in the society and the different levels of physical activity between societies. A study conducted in Turkey has found the mean TUG scores of the elderly to be $16.62 \pm 7.38$ seconds (Onat, Delialioglu, \& Ozel, 2014). Results of this study also support the literature.

This study found the mean BBS score to be $43.48 \pm 17.23$ (Table 2). Individuals with a BBS score less than 45 have been associated with increased fall risk. A statistically significant relationship was found between the BBS score and physical functionality (Kornetti, Fritz, Chiu, Light, \& Velozo, 2004). Studies have been conducted that compare the BBS scores of groups with and without a fall history. In addition to studies that find lower scores (Herman, Giladi, \& Hausdorff, 2011), some studies have not found any difference between groups with and without a fall history (Desai, Goodman, Kapadia, Shay, \& Szturm, 2010). This has been determined as the fear of falling in parallel with slowing and decreasing physical activity. Although different findings are shown in the literature, the BBS results of this study indicated that the elderly who had a fall risk had a low level of balance, which negatively affects successful aging.

Lower handgrip strength is related to falls, general muscle weakness, impaired quality of life, increasing hospitalization duration and mortality (Roberts et al., 2011). This study found a mean HST score for the dominant hand and the other hand to be $46.56 \pm 19.31$ and $42.45 \pm 19.25$, respectively (Table 2). Another study with the same mean age as this study has found the mean HST score for the dominant hand and the other hand to be $45.63 \pm 21.16$ and 43.65 \pm 23.58 , respectively (Evcik \& Kizilay, 2001). These results show an obvious similarity with the findings of this study. 


\section{Isik et al. - Successful Aging Levels of Nursing Home Residents}

When study results were evaluated in terms of cognitive functionality; SMMSE is a valid and reliable test for mild dementia diagnosis in Turkish society, and its ideal threshold value has been determined as 23/24 (Güngen et al., 2002). This study found the mean SMMSE score and internal consistency to be $23.57 \pm 3.02$ and 0.779 , respectively (Table 2 ). This result indicated that elderly participating in the study were on the verge of mild cognitive disorder and vulnerable in terms of functionality component.

Klusmann et al. (2010) reported that elderly who are inactive in terms of physical activity have lower scores in the SMMSE. Aarsland et al. (2010) have determined that as the level of physical activity increases in the elderly, their cognitive situations improve. Relationship of physical and cognitive component results of this study showed similarities with the literature.

Physiological, psychological, and social benefits of physical activity support successful aging (Carr \& Weir, 2017). This study also found a coherent relationship between muscular strength, balance, mobility and ADL parameters and cognitive situation and social parameters and literature.

When active engagement with life was evaluated, participants' mean SCS score was found to be $25.23 \pm 8.89$ (Table 2). When it was evaluated based on the highest level obtainable from the scale, it revealed a social connectedness above average. Additionally, social connectedness was affected by age and level of physical functionality (Table 4). Participants under 75 years of age had higher social connectedness level than those over 75 years of age $(p<0.05$; $\mathrm{p}<0.01$ ) (Table 4). With increasing age, loss of individuals who are loved and comprised social circle may increase, which negatively affects social connectedness. Increasing age also causes a decrease in physical functionality resulting in loss of autonomy and independence. Aging also affects competencies such as managing a healthy lifestyle needs, personal development, and social connectedness (Rogers \& Mitzner, 2017). This study indicated a relationship between income level and social connectedness $(\mathrm{p}<0.05 ; \mathrm{p}<0.01)$ (Table 4). Lamu and Olsen (2016) have stated that income level affects both personal well-being and social connectedness. Income level, in terms of being a facilitating factor in fulfilling needs, may provide individuals a feeling of well-being and easy communication with the people around.

Participants' mean PWI-A score was found to be $51.68 \pm 18.60$ (Table 2). Considering the highest score obtainable from the scale, the personal well- 
being perception is above average. Previous studies indicate that physical, psychological, and social factors directly affect personal well-being (Bullo et al., 2015; Reker, 1997). This study is also in compliance with the literature in terms of the statistically significant relationship between PWI-A and mean SCS, BBS, and TUG scores ( $\mathrm{p}<0.05 ; \mathrm{p}<0.01)$ (Table 3).

Limitation: This study is not without limitations. First, the population sampled is restricted, both geographically and ethnically, to Turkish nursing home residents. Thus, the results that emerged from the present study may not be applicable to participants who are from different ethnic populations or who choose not to participate in research. Second, some of the variables (sociodemographics e.g.) were obtained from proxy ratings. Proxy reports might be more objective and realistic compared with self-ratings (e.g., health information, economic status), whereas older adults may view life as more or less positive.

\section{Conclusion}

This study was conducted to determine successful aging and the conditions of successful aging of nursing home residents. This study found that elderly individuals had a disease incidence negatively affecting successful aging and diabetes negatively affected physical functionality. Additionally, they had a vulnerable level of cognitive function, high fall risk and a personal well-being index above average in terms of commitment to life that can positively affect successful aging, and social connectedness. This study made a genuine contribution to the successful aging of the individuals participating in the study. Each subcomponent (low level of disease and disability level regarding the disease, high quality of cognitive and physical functionality and active engagement to life) affects and is affected by successful aging in this study formed with Rowe's (2015) model regarding successful aging.

Based on these results, the following conclusions can be made: effectively manage chronic disease before reaching old age, develop a multidisciplinary program to increase physical and cognitive functions in nursing homes, as well as a special approach based on age groups to increase social connectedness. This study represents a limited number of nursing home residents. A further study comprising elderly individuals living in a nursing home and society may provide more data. 
74 Isik et al. - Successful Aging Levels of Nursing Home Residents

\section{References}

Aarsland, D., Sardahaee, F. S., Anderssen, S., Ballard, C., \& group, t. A. s. S. S. R. (2010). Is physical activity a potential preventive factor for vascular dementia? A systematic review. Aging \& mental health, 14(4), 386-395. https://doi.org/10.1080/13607860903586136

Arias-Merino, E. D., Mendoza-Ruvalcaba, N. M., Arias-Merino, M. J., Cueva-Contreras, J., \& Vazquez Arias, C. (2012). Prevalence of successful aging in the elderly in Western Mexico. Current gerontology and geriatrics research, 2012. https://doi.org/10.1155/2012/460249

Arik, G., Varan, H. D., Yavuz, B. B., Karabulut, E., Kara, O., Kilic, M. K., . . - Yesil, Y. (2015). Validation of Katz index of independence in activities of daily living in Turkish older adults. Archives of gerontology and geriatrics, 61(3), 344-350. https://doi.org/10.1016/j.archger.2015.08.019

Bellace, J. V., Healy, D., Besser, M. P., Byron, T., \& Hohman, L. (2000). Validity of the Dexter Evaluation System's Jamar dynamometer attachment for assessment of hand grip strength in a normal population. Journal of hand therapy, 13(1), 46-51. https://doi.org/10.1016/S0894-1130(00)80052-6

Bogle Thorbahn, L. D., \& Newton, R. A. (1996). Use of the Berg Balance Test to predict falls in elderly persons. Physical therapy, 76(6), 576583. https://doi.org/10.1093/ptj/76.6.576

Bohannon, R. W. (2006). Reference values for the timed up and go test: a descriptive meta-analysis. Journal of Geriatric Physical Therapy, 29(2), 64-68. https://doi.org/10.1519/00139143-200608000-00004

Bullo, V., Bergamin, M., Gobbo, S., Sieverdes, J., Zaccaria, M., Neunhaeuserer, D., \& Ermolao, A. (2015). The effects of Pilates exercise training on physical fitness and wellbeing in the elderly: a systematic review for future exercise prescription. Preventive medicine, 75, 1-11. https://doi.org/10.1016/j.ypmed.2015.03.002

Bülow, M. H., \& Söderqvist, T. (2014). Successful ageing: A historical overview and critical analysis of a successful concept. Journal of Aging Studies, 31, 139-149. https://doi.org/10.1016/j.jaging.2014.08.009 
Carr, K., \& Weir, P. L. (2017). A qualitative description of successful aging through different decades of older adulthood. Aging \& mental health, $21(12)$,

1317-1325.

\section{doi:https://doi.org/10.1080/13607863.2016.1226764}

Chiaranai, C., Chularee, S., \& Srithongluang, S. (2018). Older people living with chronic illness. Geriatric Nursing, 39(5), 513-520. https://doi.org/10.1016/j.gerinurse.2018.02.004

Dahany, M.-M., Dramé, M., Mahmoudi, R., Novella, J.-L., Ciocan, D., Kanagaratnam, L., . . . Barbe, C. (2014). Factors associated with successful aging in persons aged 65 to 75 years. European Geriatric Medicine, $5(6)$ 365-370. doi:https://doi.org/10.1016/j.eurger.2014.09.005

Dent, O., Waite, L., Bennett, H., Casey, B., Grayson, D., Cullen, J., . . Broe, G. (1999). A longitudinal study of chronic disease and depressive symptoms in a community sample of older people. Aging \& mental health, 3(4), 351-357. https://doi.org/10.1080/13607869956136

Desai, A., Goodman, V., Kapadia, N., Shay, B. L., \& Szturm, T. (2010). Relationship between dynamic balance measures and functional performance in community-dwelling elderly people. Physical therapy, 90(5), 748-760. https://doi.org/10.2522/ptj.20090100

Duru, E. (2007). An adaptation study of social connectedness scale in Turkish culture. Eurasian Journal of Educational Research, 26, 85-94.

Ekström, H., Dahlin-Ivanoff, S., \& Elmståhl, S. (2011). Effects of walking speed and results of timed get-up-and-go tests on quality of life and social participation in elderly individuals with a history of osteoporosis-related fractures. Journal of aging and health, 23(8), 1379-1399. https://doi.org/10.1177/0898264311418504

Evcik, D., \& Kizilay, B. (2001). Correlation of hand grip strength and disability in daily living activities in geriatric patients. Turkish Journal of Geriatrics, 4(1), 11-14.

Folstein, M. F., Folstein, S. E., \& McHugh, P. R. (1975). "Mini-mental state": a practical method for grading the cognitive state of patients for the clinician. Journal of psychiatric research, 12(3), 189-198. https://doi.org/10.1016/0022-3956(75)90026-6

Günal, A., Başkurt, F., Başkurt, Z., Parpucu, T. İ., \& Yücekaya, B. (2012). Relationship between perception of handicap and functional disability 
76 Isik et al. - Successful Aging Levels of Nursing Home Residents

in elderly patients with type 11 diabetes. SDÜ Health Sciences Journal, 3(1), 31-35.

Güngen, C., Ertan, T., Eker, E., Yaşar, R., \& Engin, F. (2002). Reliability and validity of the standardized Mini Mental State Examination in the diagnosis of mild dementia in Turkish population. Turkish journal of psychiatry, 13(4), 273-281.

Herman, T., Giladi, N., \& Hausdorff, J. M. (2011). Properties of the 'timed up and go'test: more than meets the eye. Gerontology, 57(3), 203-210. https://doi.org/10.1159/000314963

Katz, S., Ford, A. B., Moskowitz, R. W., Jackson, B. A., \& Jaffe, M. W. (1963). Studies of illness in the aged: the index of ADL: a standardized measure of biological and psychosocial function. JaMa, 185(12), 914-919. https://doi:10.1001/jama.1963.03060120024016

Keskinoglu, P., Ucku, R., Yener, G., Yaka, E., Kurt, P., \& Tunca, Z. (2009). Reliability and validity of revised Turkish version of Mini Mental State Examination (rMMSE-T) in community-dwelling educated and uneducated elderly. International journal of geriatric psychiatry, 24(11), 1242-1250. https://doi.org/10.1002/gps.2252

Klusmann, V., Evers, A., Schwarzer, R., Schlattmann, P., Reischies, F. M., Heuser, I., \& Dimeo, F. C. (2010). Complex mental and physical activity in older women and cognitive performance: a 6-month randomized controlled trial. Journals of Gerontology Series A: Biomedical Sciences and Medical Sciences, 65(6), 680-688. https://doi.org/10.1093/gerona/glq053

Kornetti, D. L., Fritz, S. L., Chiu, Y.-P., Light, K. E., \& Velozo, C. A. (2004). Rating scale analysis of the Berg Balance Scale. Archives of physical medicine and rehabilitation, 85(7), 1128-1135. https://doi.org/10.1016/j.apmr.2003.11.019

Lamu, A. N., \& Olsen, J. A. (2016). The relative importance of health, income and social relations for subjective well-being: an integrative analysis. Social Science \& Medicine, 152, 176-185. https://doi.org/10.1016/j.socscimed.2016.01.046

Lau, A. L., Cummins, R. A., \& Mcpherson, W. (2005). An investigation into the cross-cultural equivalence of the Personal Wellbeing Index. Social Indicators Research, 72(3), 403-430. https://doi.org/10.1007/s11205-004-0561-z 
Lee, R. M., \& Robbins, S. B. (1995). Measuring belongingness: The social connectedness and the social assurance scales. Journal of counseling psychology, 42(2), 232. https://doi.org/10.1037/0022-0167.42.2.232

Marengoni, A., Angleman, S., Melis, R., Mangialasche, F., Karp, A., Garmen, A., ... Fratiglioni, L. (2011). Aging with multimorbidity: a systematic review of the literature. Ageing research reviews, 10(4), 430-439. https://doi.org/10.1016/j.arr.2011.03.003

Meral, B. F. (2014). Psychometric properties of Turkish form of the Personal Well-Being Index-Adult. The Journal of Happiness \& Well-Being, 2, 119-131.

Misajon, R., Pallant, J., \& Bliuc, A.-M. (2016). Rasch analysis of the personal wellbeing index. Quality of Life Research, 25(10), 2565-2569. https://doi.org/10.1007/s11136-016-1302-x

Moore, S. L., Metcalf, B., \& Schow, E. (2006). The quest for meaning in $\begin{array}{lll}\text { aging. } \quad \text { Geriatric 293-299. } & \text { Nursing, 27(5), }\end{array}$ https://doi.org/10.1016/j.gerinurse.2006.08.012

Onat, S. S., Delialioglu, S. U., \& Ozel, S. (2014). The relationship of balance between functional status and quality of life in the geriatric population/Geriatrik populasyonda dengenin fonksiyonel durum ve yasam kalitesi ile iliskisi. Turkish Journal of Physical Medicine and Rehabilitation, 60(2),

147-155. https://doi.org/10.5152/tftrd.2014.67366

Podsiadlo, D., \& Richardson, S. (1991). The timed "Up \& Go": a test of basic functional mobility for frail elderly persons. Journal of the American geriatrics Society, 39(2), 142-148. https://doi.org/10.1111/j.15325415.1991.tb01616.x

Reker, G. T. (1997). Personal meaning, optimism, and choice: Existential predictors of depression in community and institutional elderly. The $\begin{array}{lll}\text { gerontologist, } & \text { 709-716. }\end{array}$ https://doi.org/10.1093/geront/37.6.709

Roberts, H. C., Denison, H. J., Martin, H. J., Patel, H. P., Syddall, H., Cooper, C., \& Sayer, A. A. (2011). A review of the measurement of grip strength in clinical and epidemiological studies: towards a standardised approach. Age and ageing, 40(4), 423-429. https://doi.org/10.1093/ageing/afr051

Rogers, W. A., \& Mitzner, T. L. (2017). Envisioning the future for older adults: Autonomy, health, well-being, and social connectedness with 
78 Isik et al. - Successful Aging Levels of Nursing Home Residents

$\begin{array}{llll}\text { technology support. } & \text { Futures, } & 87, & 133-139 .\end{array}$ https://doi.org/10.1016/j.futures.2016.07.002

Rowe, J. W., \& Kahn, R. L. (1997). Successful aging. The gerontologist, 37(4), 433-440. https://doi.org/10.1093/geront/37.4.433

Rowe, J. W., \& Kahn, R. L. (2015). Successful aging 2.0: Conceptual expansions for the 21st century. The Journals of Gerontology: Series B, 70(4), 593-596. https://doi.org/10.1093/geronb/gbv025

Sahin, F., Yilmaz, F., Ozmaden, A., Kotevoglu, N., Sahin, T., \& Kuran, B. (2008). Reliability and validity of the Turkish version of the Berg Balance Scale. Journal of Geriatric Physical Therapy, 31(1), 32-37. https://doi.org/10.1519/00139143-200831010-00006

Trost, J. E. (1986). Statistically nonrepresentative stratified sampling: A sampling technique for qualitative studies. Qualitative sociology, 9(1), 54-57. https://doi.org/10.1007/BF00988249

Üner, S., Balcılar, M., \& Ergüder, T. (2018). National Household Health Survey- Prevalence of Noncommunicable Disease Risk Factors in Turkey 2017. WHO Turkey Office, Ankara.

Wong, E., Backholer, K., Gearon, E., Harding, J., Freak-Poli, R., Stevenson, C., \& Peeters, A. (2013). Diabetes and risk of physical disability in adults: a systematic review and meta-analysis. The lancet Diabetes \& endocrinology, $\quad 1(2), \quad 106-114 . \quad$ https://doi.org/10.1016/S22138587(13)70046-9

World Health Organization (2016). World Report on Ageing and Health.[Sl]: World Health Organization, 2015. Acesso em, 2(05).

Emir Ibrahim Isik. Lecturer of Therapy and Rehabilitation Department, Vocational School of Health Services, Cukurova University. eisik@cu.edu.tr

Ayse Inel Manav. Osmaniye Korkut Ata University, Health Sciences Faculty, Nursing Department, Osmaniye/Turkey.

Saliha Bozdogan Yesilot. Department of Nursing, Faculty of Health Science, Cukurova University, Adana, Turkey. 